\title{
Complicaciones de la cirugía de reasignación de sexo
}

\author{
Cuesta Presedo JM, Sánchez Zalabardo D, Ascaso Cornago I.
}

Fundación Hospital Calahorra.

Actas Urol Esp. 2006;30(9):966

$\mathrm{P}$ aciente de 30 años de edad, de sexo femenino, con antecedente clínico de una cirugía de reasignación de sexo realizada en otro centro 5 años atrás, que presenta dificultad miccional con sensación de micción inconclusa y episodios ocasionales de hematuria macroscópica.

A la exploración destaca un neopene normoimplantado y constituido a expensa del músculo recto anterior del abdomen, asimismo, se aprecia una vagina ocluida siendo imposible la localización del meato uretral externo. Labios mayores integros.

A la urografia se aprecia en placa simple una gran litiasis intravesical con función renal normal y ligera ectasia de ambos uréteres.

Se le realiza al paciente una cistolitectomía.

Posoperatorio con desaparición total de la clínica por la que acudió a nuestra consulta.

Dr. J.M. Cuesta Presedo

Paletillas, 3 - $7^{\text {o }}$ Izda.

26500 Calahorra (La Rioja)

E-mail: jcuesta@fhcalahorra.com

(Trabajo recibido el 23 de noviembre de 2005)

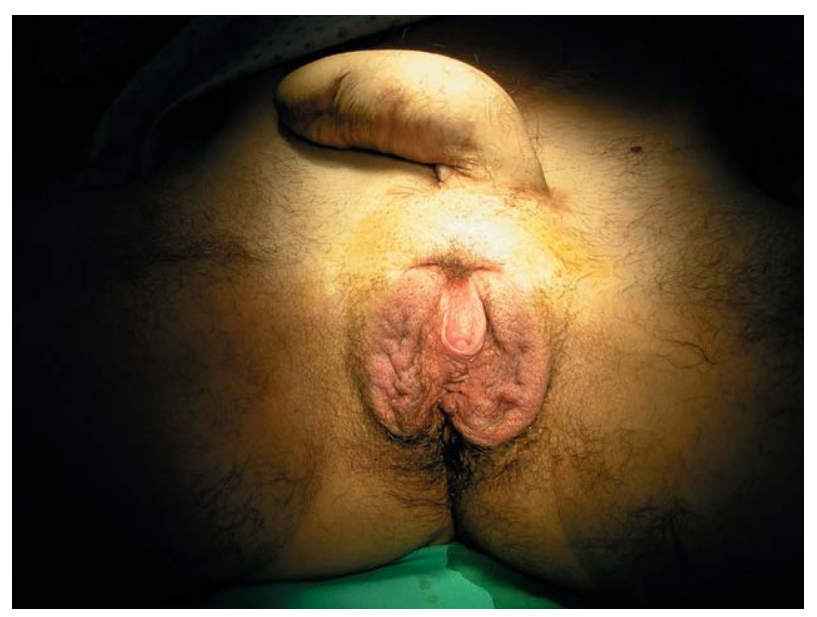

FIGURA 1. Genitales externos tras la cirugía.

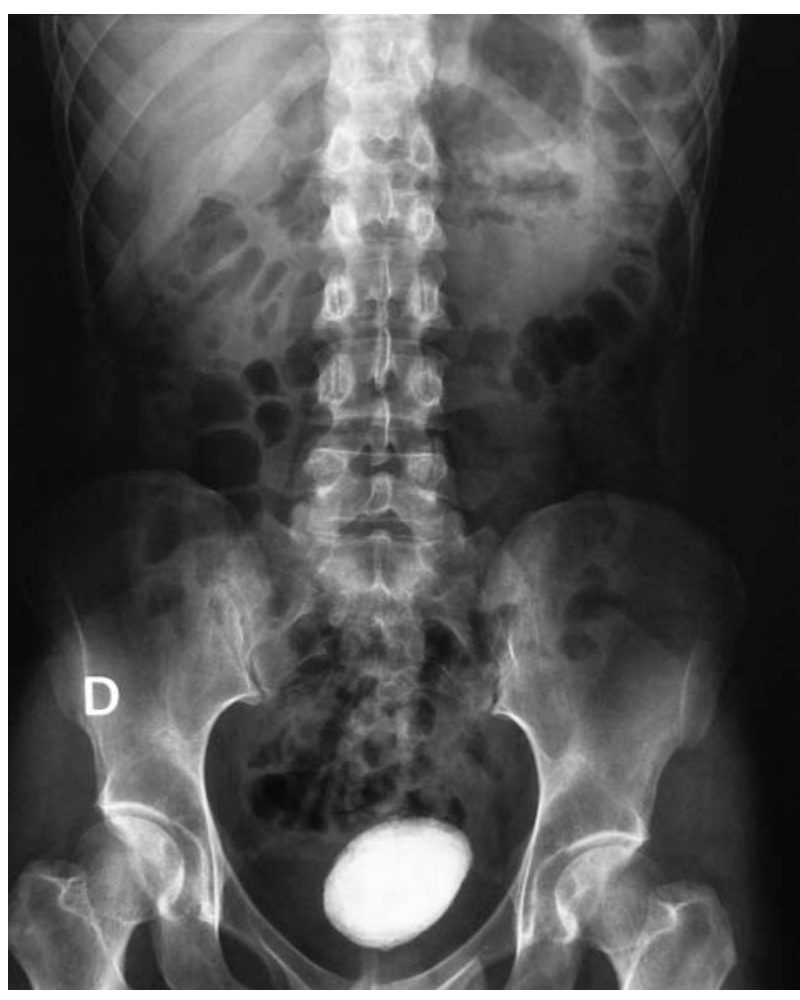

FIGURA 2. Radiografía simple de abdomen previa a la cirugia.

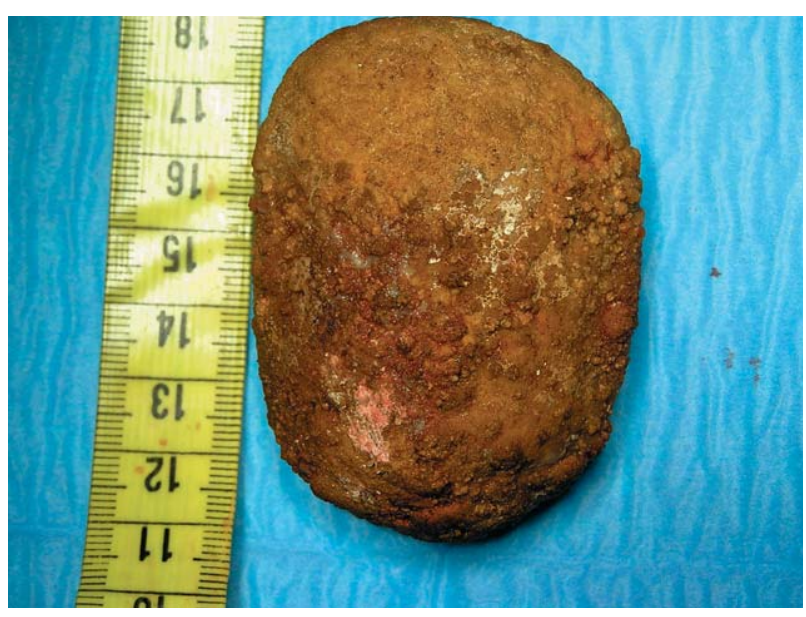

FIGURA 3. Litiasis vesical. 